\title{
THE ASSUMPTIONS OF PROINNOVATIVE INDUSTRIAL POLICY IN POLAND AND CHINA
}

\begin{abstract}
The author presents issues of proinnovative industrial policy in Poland and China. He describes the reasons for this policy in current conditions of the economies of the aforementioned countries. The author analyses certain former circumstances regarding the systems of the states and national economies in Poland and China. He presents the valid contents of proinnovative industrial policy in the aforementioned states. The author recognises strict connections between important challenges ahead of both countries and contents of their proinnovative industrial policies.
\end{abstract}

Keywords: innovative policy, industrial policy, Poland, China

Streszczenie

\section{Założenia proinnowacyjnej polityki przemysłowej w Polsce i Chinach}

Autor przedstawia zagadnienia proinnowacyjnej polityki przemysłowej w Polsce i Chinach. Opisane zostały przyczyny prowadzenia tych polityk w obecnych warunkach gospodarczych wymienionych państw. Przeanalizowano wcześniejsze okoliczności związane z systemami państwowymi i gospodarkami narodowymi Polski i Chin. Zaprezentowano także treść współczesnych polityk proinnowacyjnych w Polsce i Chinach. Autor zidentyfikował bezpośredni związek pomiędzy ważnymi wyzwaniami stojącymi przed państwami a zawartością ich proinnowacyjnych polityk przemysłowych.

Słowa kluczowe: polityka innowacyjna, polityka przemysłowa, Polska, Chiny

\section{Introduction}

China and Poland are trying to be more innovative and avoid a trap of middle growth. The aim of the article is to analyse how assumptions of innovative industrial policies in Poland and China are related. The author's concept of the existence of a set of similarity between factors and circumstances of social-economic lives in both countries. Some challenges are similar too. The author 
analyses especially documents of the European Union and polish government, Chinese $13^{\text {th }}$ Five Year Plan, program declarations and speeches of the lead-officials of the Chinese state. Finally, he recognises strict connections between important challenges ahead of both countries and contents of their proinnovative industrial policy.

The author recognizes the term proinnovative industrial policy as a combination of terms: the innovative policy and the industrial policy.

Bengt-Ake Lundvall and Susana Borras state that the innovative policy includes the scientific and the technological policy. The main focus of the innovative policy should be the overall innovative performance of the economy. There are many possible instruments of the innovative policy such as: improving organizational performance and learning, developing information society, competition and environmental regulation, improving social capital for regional development, intelligent and democratic forecasting, etc. [Fagerberg et al., 2006: 519-616]. Lukasz Mamica mentions that innovative policy can be defined as: "Activity of public authorities and other entities (such as universities or research institutes) aimed at creating conditions for growth of competitiveness and improving quality of life in citizens through the rise and development of innovations (taking into account coordinative activities in the sectors of science, education and in the field of research and development)" [Geodecki, Mamica, 2014: 16; comp. Vonortas et al., 2015: 10 and $n$.].

Murat Yülek states that industrial policy and economic planning are bi-directionally related [Yülek, 2015, p. 21]. One can meet with many concepts of industrial policy. For example, Jacques Pelkmans recognizes wide concept of industrial policy which consist of: framework aspects (functioning of the market, better regulation, competition policy, etc.), horizontal industrial policy (research strategies, entrepreneurship and risk capital, skills and human capital, etc.), sectoral (specific) industrial policy (sectoral interventions, specific aspects of regional and cohesion policies, technology policies, etc.) [Bianchi, Labory, 2006: 47]. Henryk Kozarowicz and Agnieszka Skowrońska mention that the concept of industrial policy concerns not only industry, but also wider understood structures of an economy. The notion of the strategy of the industry development is only an approximate concept to the notion of industrial policy [Kozarowicz, Skowrońska, 2005: 9-15]. The author can state that this term has more open than close character.

\section{The reasons for the policy}

\section{I. Current conditions of economy}

One can declare that the current situations of the economies of China and Poland are far from the state of true crisis. Perhaps both national economies analysed are not growing so fast as the states wish, but the author can say that economies 
of these countries are on the long-term path of growth. Alarming news from the specific Chinese (limited and restricted) stock exchange market or about specific dispute considering legal relations between specific Constitutional Tribunal and other public powers in Poland are not significant symptoms of important macro-economic troubles now.

The basic, valid economic data of China are: (1) GDP growth rate in the year 2015 was $6.75 \%$ (in 2010 it was $10.2 \%$ and the projected rate for 2017 is $6.2 \%$ ); (2) the total population is about 1.4 billion people; (3) GDP at market prices is about 10.5 trillion USD (13 171 USD per capita); (4) commitments in the fiscal year 2015 amounted to 1850 million USD. Today's data for Poland are: (1) GDP growth rate during the year 2015 was 3.5\% (in 2011 it was 5\% and the projected rate for 2017 is $3.5 \%$ ); (2) the total population is circa 38.5 million citizens; (3) GDP at market prices is about 550 billion USD (24 952 USD per capita); (4) commitments in fiscal year 2015 were 966 million USD [http://www.worldbank.org and https://data.oecd.org, access: 2016].

All know that reforms of Chinese economy and state are far from complete. Generally, the People's Republic of China continues to remain a developing country because its GDP per capita is still a fraction of GDP per capita in more developed countries. Given the current situation of a decreasing GDP growth rate Chinese national economy is searching for new drivers for social-economic growth [OECD, 2015: 10 and n.; Word Bank, 2016a: 6 and n.].

Poland can be recognised as the country that has gained a relatively high-income status (after the transition of the national economy of a former member of the Soviet bloc). However, previous engines of "post-transitional" development of the Polish economy (especially: the accumulation of capital during the exodus from the so-called "socialist" economic system, advantages of the productivity growth, huge capital transfers from the European Union) are finishing and Poland needs new drivers for growth too. Particularly, it is needed change the position on value chains which is strictly connected with strengthening the innovativeness of Polish economy [World Bank, 2016: 3 and n.; OECD, 2016: 6 and n.].

\subsection{Former circumstances regarding the systems of the states and national economies}

The Circumstances of the social-economic life in China are rooted in thousands of years of Chinese history [http://www.npc.gov.cn/englishnpc/Constitution/ node_2825.htm, access: 2016], which began about thousand years before settlement the Rome [Zhang, 2015: 139 and n.]. The ancient Chinese thought recommends: the value of an education, a necessity of harmony in all social organizations (in the state too); the main power of governing should be a moral virtue rather than a law; assurance of economic welfare is an indispensable condition for improving people's morality (and - as a consequence - gaining the harmony in the state). Confucius claims there are three necessary requirements for good governing: food for the people (i.e. securing their basic needs), a strong army 
(what one can recognise today as a good level of national security) and a trust of the nation for governors [Schwartz, 2009: 104-110; Brzozowska, Mikusińska, 2016: 203-219].

Chinese rulers, commanders and thinkers present an opposing view of matters of planning and strategy than a typical, direct, western point of view. They prefer twisting paths to victories (i.e. gaining their targets). Frontal clashes of phalanxes (which was typical of ancient Greeks) are an extreme without any alternatives in the tradition of the Chinese management. The best communicate in the tradition of Chinese public life is a complex and subtle courtly poem. Confucius states that each wording is temporary and each is not reservedly enough. Chinese master does not speak but shows. He does not communicate but notices. There are many differences in understanding of the world between the minds of Western and Eastern people. The subtlety of an indirectly way can be often hard to interpret for people from other parts of the world [Jullien, 2006: 15-260].

For last five hundred years' development of social-economic life in China has been under various influences of the Western civilization. Contacts during the first three hundred years were less intense. During this period envoys of the West such as, the Jesuit Order, especially tried to propagate Christianity in the Far East (with minor final results), but also cooperated on many technological issues such as constructing of mechanical clocks or canons [Klarecki, 2014: 118]. The nineteenth century brought a collapse of Chinese sovereignty. It was the century of "gun-boat justice" and looting the emperor's palace in Beijing by European expeditionary forces. Colonial powers were removed from the Chinese land by Japanese aggressor during the wider-understood period of the Second World War (which was cruel for China and brought about a lot of damage) [Kirchberger, 2015: 29]. At the end of the seventies of the former century, the Communist Party of China started the transition of Chinese state and economy [Cieślik, 2015: 12 and $\mathrm{n}$.].

The valid Chinese paradigm of development assumes: active role of the state in economy; non-ideological and pragmatic methods of reform; general rule that material needs of citizens are more important than their individual liberties ("priority of market rather than democracy"); conducting of Chinese development by well-chosen elites which are conscious of strategic purposes of the country; relative openness of China to the world (for needs of growth and generally within the borders of it); using "Chinese soft power" in international relations and non-involvement directly into military conflict [Dziak et al., 2012: 225-226]. The author can state that maybe the last what will be changed - will be the official names of the governing party and the state.

The Chinese constitution proclaims: a disruption of the socialist system is prohibited; the organs of the state apply the principle of democratic centralism; the state ensures the consolidation and growth of the state-owned economy; non-public sectors of the economy are an important component of the socialist market economy; the state encourages, supports and guides the development of the non-public sectors of the economy; the state promotes the development of the natural and social sciences, disseminates knowledge of science and technology, commends and 
rewards achievements in scientific research as well as technological innovations and inventions; the state encourages and assists creative endeavours conducive to the interests of the people that are made by citizens engaged in education, science, technology. ${ }^{1}$

The Polish statehood is about one thousand years old. Generally, Poland was under influences of the West during European Middle Ages. The country's economic system and the system of the state did not transform properly during the era of the European colonisation (i.e. after the year 1500). During the eighteenth century Poland was divided between three neighboring, modern empires. The country was shortly independent during both world wars. The Second World War brought many losses. After the war Poland was a part of the Soviet bloc. Since the nineties of previous century Poland has transformed into directions of modern economy with important role of mechanisms of free market and an effective state of law (since 2004 as a member state of the European Union and since 1999 as a member state of the North Atlantic Treaty Organization) [Ministry of Foreign Affairs, 2014: 59-215; https://www.cia.gov/library/publications/the-world-factbook/geos/ pl.html; http://www.economist.com/news/special-report/21604684-first-time-halfmillennium-poland-thriving-says-vendeline-von-bredow; https://www.premier. gov.pl/en.html [access to all: 1.06.2016].

Polish constitution claims: the country shall be a democratic state ruled by law and implementing the principles of social justice; a social market economy, based on the freedom of economic activity, private ownership, and solidarity, dialogue and cooperation between social partners, shall be the basis of the economic system of the Republic of Poland; limitations upon the freedom of economic activity may be imposed only by means of statute and only for important public reasons. ${ }^{2}$

The Treaty of Lisbon (the records of which concern Poland as a member state of the European Union) proclaims: "The Union shall establish an internal market. It shall work for the sustainable development of Europe based on balanced economic growth and price stability, a highly competitive social market economy, aiming at full employment and social progress, and a high level of protection and improvement of the quality of the environment. It shall promote scientific and technological advance". This document also contains a declaration, that states: "The Union

1 The Constitution of the People's Republic of China, Chapter I General Principles and Chapter II The Fundamental Rights and Duties of Citizens (http://www.npc.gov.cn/englishnpc/Constitution/ node_2825.htm, access: 1.06.2016). One can find current news from Xinhua Agency about endeavours of Chinese authorities of propagating these proinnovative records of their constitution. For example - on the $29^{\text {th }}$ of April 2016, Chinese President Xi Jinping asked officials to place more trust in intellectuals, welcome their criticism and limit interference in their creative work. He encouraged scientists to take the lead in the innovation drive, sharpen creativity and contribute to the country's economic and social development as well as improve a welfare of citizens (http://news.xinhuanet. com/english/2016-04/30/c 135324021.htm, access: 1.06.2016).

2 The Constitution of the Republic of Poland (http://www.sejm.gov.pl/prawo/konst/angielski/ konse.htm, access: 1.06.2016). One can read in English exemplifications of interpreting of these records in chosen verdicts of Polish Constitutional Tribunal (http://trybunal.gov.pl/en/case-list/judicial-decisions, access: 1.06.2016). 
aims at achieving balanced economic growth and price stability. Economic and budgetary policies thus need to set the right priorities towards economic reforms, innovation, competitiveness and strengthening of private investment and consumption in phases of weak economic growth". ${ }^{3}$

The needs of recent proinnovative industrial policies in the two countries are similar. China and Poland are trying to be more innovative and avoid a trap of middle growth. The author's concept of the existence of a set of similarity between factors and circumstances of social-economic lives in both countries over the last few centuries and now.

\subsection{Today's challenges of the social-economic life}

The author can mention that China is a major country and its problems are not rarely major too. Generally, he recognizes that official Chinese sources inform about them directly and indirectly. Many sources have substantial uncritical or unfriendly attitude to the People's Republic of China.

One can indicate more important valid challenges of the Chinese social-economic life: high inequalities (not only inside society, but between parts of the country); rapid developmental processes (which harm not only the environment, but also social connections - especially industrialization and urbanisation); difficulties in gaining minimum middle-income status (for majority of the huge population of the state); ethnical and religious separatisms (the country is not homogeneous), excess of information for needs of Chinese society (today the Great Chinese Wall is the National Firewall), complex political and military situation around China (especially controversies over where the territory of the People's Republic of China begins), anxieties of not possessing the military supremacy in the region (which are connected with memories - from last two centuries - of being a victim of aggressive actions of foreign powers); slowing of the growth of Chinese economy (stable and gradual since the year 2010); often difficult access to basic public services (especially education); corruption (trials of top-ranked officials and commanders during the last few years who had problems with "party's discipline" have informed about the problem) and the largest, quantitative size of public administration on the planet (circa about 50 million of public servants) [Cabestan, 2013: 65-121; Word Bank, 2016b: 3 and next; Góralczyk, 2010: 72; Behrendt, 2015: 7 and n.; Xi Jinping, 2014: 37; OECD, 2015: 14 and $n$.].

The social-economic life in Poland is not without any challenges. The two most important are aforementioned: finishing previous engines of "post-transitional" development of Polish economy and it's not satisfying position on value chains of

\footnotetext{
3 Treaty of Lisbon amending the Treaty on European Union and the Treaty establishing the European Community (http://eur-lex.europa.eu/legal-content/EN/TXT/PDF/?uri=OJ:C:2007:306:FULL $\&$ from=PL, access: 1.06.2016). Bodies of the European Union are conducting many proinnovative initiatives such as European Innovation Council, which is new collecting ideas and advising institution (http://ec.europa.eu/research/eic//index.cfm, access: 1.06.2016).
} 
global economy. The other relevant problems are: the valid growth rate is stable, but not so high (as during previous years); the author can state that the country is still divided (into social-economic cultures of three empires which ruled over Polish territory till the end of the First World War - especially the most significant contrasts are between former territories of Germany and Russia); metropolitan territories with high, accumulated growth and many territories without it; benefits of the development after collapse of the Soviet bloc have not been shared equally; necessity of reform of the public finances (including the social protection which begins to face demographical processes); improper use of a capital of well-educated society (and relatively significant potential of universities and other research institutes); a common advantage of statistical Polish firm is still low costs of work; a lack of national financial capital; the country has one of the least innovative economies in the OECD (the report of the European Union from the year 2015 is not optimistic) [Hausner, 2013: 118-132; European Commission, 2015: 31; Ministerstwo Rozwoju, 2016: 9-62; OECD, 2016: 14 and n.; World Bank, 2016: 2-7]. ${ }^{4}$ All these challenges can guide Poland to the "middle-income trap".

\section{Valid contents of proinnovative industrial policy}

\section{I. Current sources of the officially declared policy}

Today's the most important publicized source about Chinese proinnovative industrial policy for the foreigner researcher are information considering new Chinese $13^{\text {th }}$ Five Year Plan, program declarations and speeches of the lead-officials of the Chinese state (especially president Xi Jinping); reports and statements by international economic or research institutes, valid scientific literature concerning Chinese matters, essential news from China (for example from Xinhua Agency), reliable economic data, current communicates of Chinese governing bodies and their applicable regulations of law in force.

The most important barrier for the foreigner researcher from Western world is not ignorance of the official Chinese language but aforementioned "subtlety of the indirect way" and their ancient methods of programming and implementing strategies which suggest not informing completely about all contents of the strategy [Giles, 1910: 1-25].

The following valid sources about the policy in the Republic of Poland can be recognised: documents of the European Union (such as strategy "Europe 2020"), statistical data (Eurostat and Central Statistical Office of Poland), program documents or declarations of Polish government (for example Morawiecki's Plan),

${ }^{4}$ Some sources are informing about growing the risk of political unpredictable in Poland, but the author does not recognize it as the most important problem for Polish economy now (for example: http://www.eulerhermes.com/economic-research/country-reports/Pages/Poland.aspx, access: 1.06.2016). 
current news or communicates from reliable institutes concerning social-economic life in Poland (such as Polish Agency for Enterprise Development). ${ }^{5}$

\subsection{Today's character of the national policy}

Between the autumn of 2015 (the party) and the spring 2016 (the parliament) authorities of China accepted $13^{\text {th }}$ Five-Year Plan (2016-2020). Chinese prime minister Li Keqiang has described the plan using sentences: "the next five years will be a crucial stage for us to build a moderately prosperous nation" and "if we can fulfil this important step, then China will be able to circumvent the middle income trap" [http://english.gov.cn/premier/news/2015/11/17/content_281475236779801.htm, access: 2016]. Presentations of the plan on Chinese governmental portals directly and indirectly show that the issues of the plan concern many aspects of social-economic life (especially the aforementioned challenges of Chinese development - for example - ambitious goal of levelling inequalities inside China). The Communist Party of China published in March 2016 a document (concerning the plan), which claims that: "By 2020, an institutional environment and a policy and law system in line with innovation-driven development will have been formed in China, which will effectively guarantee a transformation of China to an innovation-oriented country" [http://english.gov. cn/2015/12/29/content_281475262707599.htm, access: 2016].

In previous years a collection of speeches of Chinese president Xi Jinping was published in many languages of the world. It contains many speeches concerning various aspects of governing of his country. Xi Jinping speaks about proinnovative policy too. For example, in his speech from the $9^{\text {th }}$ June 2014, which was entitled "Transition to Innovation-driven growth" he stated: "In the face of new trends of scientific and technological innovation, the world's major countries are seeking to make new scientific and technological breakthroughs and gain competitive edges in future economic as well as scientific and technological development. We cannot afford to lag behind in this importance race. We must catch up and then try to surpass the others". The similar envoy contains the speech from $21^{\text {st }}$ October headlined "Right Time to Innovate and Makes Dreams Come True" [Jinping, 2015].

Artur Gradziak enumerates main instruments stimulating research and development of Chinese firms: fiscal privileges, governmental credits and guarantees, Chinese own technical standards, conditions of protection of intellectual property, policy versus foreign investments, system of imposed transfer of technologies, promotions of binds between research sector and industry [Gradziak, 2013: 111-156]. The exemplification of this strategy is one of the detailed goal - changing the

${ }^{5}$ After autumn 2015 elections in Poland the new cabinet is beginning its rules and some of its programs are only signalised or declared. However, the author hopes that nobody should expect many sudden, dramatic changes in main streams of Polish government's economic policy (especially against European innovative policy). 
non-optimal situation ,made in China" to the positive, target situation „created in China" [Li Wuwei, 2011, p. XV and next; Li-Hua, 2014, p. 49 and next].

The issues of proinnovative industrial policy are still present during activities of central Chinese governing bodies. ${ }^{6}$

Today's processes of the proinnovative industry policy in China are often connected with intensive processes of modernising and development of Chinese military (especially far-range oceanic navy and high-tech air forces). It implicates technological effects not only in China, but also in the region. For example, in April 2016 the Royal Australian Navy decided to commission dozen oceanic, ultra-tech nuclear submarines "Barracuda" class in industrial cooperation with the French DNCS Group [http://en.densgroup.com/news/australian-government-selects-dens-for-the-sea-1000-future-submarine-program, access: 2016]. The author can state that one of the real strategic goals of China is the growth of the country with no possibility for the aforementioned disasters of nineteenth century to happen and stepwise creation of an ability to protect far, overseas interests of China (for example in Africa).

The Republic of Poland is a member-state of the European Union. Its innovative policy is substantially conditioned by the proinnovative policy of the Union. The strategy of economic policy "Europe 2020" which generally declares "Europe must act" and speaks about "smart growth" (developing the economy based on knowledge and innovation - as drivers). The following ideas are mentioned there: improving the quality of education, strengthening the research performance, promoting the innovation and the knowledge transfer, making full use of information and communication technologies, ensuring that innovative ideas can be turned into new products or services, etc. [European Commision, 2010].

Today the European Commission suggests Polish authorities that government agencies in Poland should face the challenge of creating operational synergies in order to integrate the research and innovation policies better (especially applied research and the commercialisation of innovative ideas). It is also important is the introduction of fast-track funding for innovation [European Commision, 2016].

The National Reform Programme "Europe 2020" which was adopted by the (former) Council of Ministers in April 2015 stated that it is necessary: to conduct actions supporting the increase of innovations, including increasing expenditure on research and development; to remove barriers for conducting business activity, to improve the quality of education to provide competent personnel, to expanding access to finance, to promote knowledge transfer, to develop business environment institutions, to stimulate cooperation between science and business. The detailed elements of the country's policy presented are: credits for technological innovations; establishment of mechanisms for the financing of research infrastructure and the activities of scientific entities; support for the development of clusters; implementation of science and research programmes and programmes fostering the cooperation

${ }^{6}$ For example, during The State Council (the Chinese cabinet) executive meeting on $20^{\text {th }}$ April 2016 - this governing body made decision to build a batch of special demonstration bases to promote mass entrepreneurship and innovation (http://english.gov.cn/policies/infographics/2016/04/21/content_281475332154713.htm, access: 1.06.2016). 
of science and industry; development of sectoral programmes for key branches of industry and other proinnovative programs (such as "Brokers of Innovation", "TOP 500 Innovators", Programme for the Support of Investments of Utmost Importance for the Polish Economy for Years 2011-2020”), etc. [Council of Ministers, 2015].

In February 2016 the new Polish government accepted the Morawiecki's plan which is declared as the long-term economic development plan for the country. The program concerns five main tasks: reindustrialization; development of innovative companies; foreign expansion; sustainable social and regional development and increase of savings [Ministerstwo Rozwoju, 2016]. In April 2016 the plan is still rather a set of declarations than a document of a detailed strategy but many mentioned aspects are present during activities of Polish authorities - especially the Ministry of Development or the Polish Agency for Enterprise Development (for example, projects "Silicon Bridge"7 or "White Paper of Innovativeness" ").

\section{Summary}

There are huge differences between the two country analysed. However, there are some similarities between certain challenges of their social-economic lives. Particularly, Chinese and Polish economies wrestle to tackle the following problems: competitiveness of low costs of work, not satisfying position on value chains of global economy, various inequalities inside the countries, the real possibility of "middle-income trap", the needs for strengthening their national securities. There are some resemblances in the histories of the both countries during the last two centuries.

China and Poland declare using innovativeness as the new driver of the growth of their economies. Both countries are going to conduct proinnovative industrial policy with using many similar methods and create their national innovation systems (which should include their governmental structures, business and universities) [Greenhalgh, Rogers, 2010, p. 87 and next].

No one knows what tomorrow will bring, ${ }^{9}$ but the proinnovative paths of the economic policies of China and Poland is convergent with the valid achievements of economics. ${ }^{10}$

7 The project supports expansion of Polish ultra-tech firms in the American "Silicon Valley" (http://www.parp.gov.pl/zaistniec-w-dolinie-krzemowej-dobre-praktyki-projektu-polski-most-krzemowy, access: 1.06.2016).

${ }^{8}$ (Governmental) The Council of Innovativeness collects hints and opinions about the conditions of the innovativeness in Poland (https://www.mr.gov.pl/strony/aktualnosci/tworzymy-biala-ksiege-innowacyjnosci, access: 1.06.2016).

${ }^{9}$ Compare reasoning about: future, capital, innovations and growth in: Piketty, 2014: 93-95.

${ }^{10}$ For example compare arguments of Mariana Mazzucato (the concept of the proinnovative "entrepreneurial state": Mazzucato, 2014: 29 and n.) or Peter Howitt and Philippe Aghion (the reasononings consider the proinnovative role of the public factor on the market and the public policy in general: Aghion, Howitt, 2015: 267 and n.). 


\section{Bibliography}

Aghion P., Howitt P. (2015), The Economics of Growth, PHI Learning, Delhi.

Behrendt P. (2015), Chińczycy graja w go, 3S MEDIA, Warszawa.

Bianchi P., Labory S. (eds.). (2006), International Handbook on Industrial Policy, Elgar, Cheltenham.

Brzozowska E., Mikusińska A. (eds.) (2016), O sztuce rzadzenia według Mozi, Mengzi, Xunzi, Han Feizi, Dialog, Warszawa.

Cabestan J. (2013), Polityka zagraniczna Chin, Dialog, Warszawa.

Cieślik E. (2015), Rozwój gospodarczy Chin od roku 1978 do kryzysu globalnego, Key Text, Warszawa.

Council of Ministers (2015), National Reform Programme "Europe 2020”, Warszawa.

Dziak W. et al. (eds.) (2012), Chiny w XXI wieku. Perspektywy rozwoju, Polska Akademia Nauk, Warszawa.

European Commission (2010), Europe 2020: A Strategy for Smart, Sustainable and Inclusive Growth, European Commission, Brussels.

European Commission (2015), Innovation Union Scoreboard 2015, European Commission, Brussels.

European Commission (2016), Commission Staff Working Document: Country Report Poland 2016, European Commission, Brussels.

Fagerberg J. et al. (eds.) (2006), The Oxford Handbook of Innovation, Oxford University Press, Oxford.

Feczko P. (2015), Uwarunkowania stosunku społeczeństwa i jednostki w Chinach a public governance, „Przegląd Prawa Publicznego”, 7-8.

Fu X. (2015), China's Path to Innovation, Cambridge University Press, Cambridge.

Geodecki T., Mamica Ł. (eds.) (2014), Polityka innowacyjna, Polskie Wydawnictwo Ekonomiczne, Warszawa.

Giles L. (ed.) (1910), Sun Tzu on the Art of War, E-Asia University of Oregon Libraries.

Góralczyk B. (2010), Chiński feniks. Paradoksy wschodzace mocarstwa, Wydawnictwo Sprawy Polityczne, Warszawa.

Gradziak A. (2013), Rola państwa w rozwoju potencjału technologicznego chińskiej gospodarki, Semper, Warszawa.

Greenhalgh C., Rogers M. (2010), Innovation, Intellectual Property and Economic Growth, Princeton University Press, Princeton.

Hausner J. (ed.) (2013), Konkurencyjna Polska. Jak awansować w światowej lidze gospodarczej, Fundacja Gospodarki i Administracji Publicznej, Kraków.

Jinping X. (2014), The Governance of China, Foreign Language Press, Beijing.

Jullien F. (2006), Drogą okrężna i wprost do celu, Wydawnictwo Uniwersytetu Jagiellońskiego, Kraków.

Kirchberger S. (2015), Assessing China's Naval Power, Springer, Berlin.

Klarecki R. (2014), Polityka Stolicy Apostolskiej wobec Chin, Mado, Torun.

Kozarowicz H., Skowrońska A. (2005), Polityka przemysłowa, Wydawnictwo Akademii Ekonomicznej we Wrocławiu, Wrocław. 
Li-Hua R. (2014), Competitiveness of Chinese Firms: West meets East, Palgrave Macmillan, New York.

Mazzucato M. (2014), Entrepreneurial State, Anthem Press, London.

Plan na rzecz odpowiedzialnego rozwoju. Informacja prasowa z 16 lutego 2016 r. (2016), Ministerstwo Rozwoju, Warszawa.

Ministerstwo Rozwoju (2016), Plan na Rzecz Odpowiedzialnego Rozwoju. Prezentacja, Ministerstwo Rozwoju, Warszawa.

Ministry of Foreign Affairs (2014), Poland's 10 years in the European Union, Ministry of Foreign Affairs, Warsaw.

OECD (2015), OECD Economic Survey: China, OECD Publishing, Paris.

OECD (2016), OECD Economic Surveys: Poland, OECD Publishing, Paris.

Piketty T. (2014), Capital in the Twenty-First Century, Harvard University Press, London.

Schwartz B. (2009), Starożytna myśl chińska, Wydawnictwo Uniwersytetu Jagiellońskiego, Kraków).

Vonortas N.S. et al. (eds.) (2015), Innovation Policy: A Practical Introduction, Springer, New York.

World Bank (2016a), Growing Challenges. East Asia and Pacific Economic Update (April), World Bank, Washington.

World Bank (2016b), Performance and Learning Review of the Country Partnership Strategy for the People's Republic of China for the Period FY13-FY16, World Bank, Washington.

World Bank (2016c), World Bank - Poland Partnership Program Snapshot. April 2016, World Bank, Washington.

Wuwei L. (2011), How Creativity is Changing China, Bloomsbury Academic, New York.

Yülek M. (2015), Economic Planning and Industrial Policy in the Globalizing Economy, Springer, Istanbul.

Zhang Q. (2015), An Introduction to Chinese History and Culture, Springer, Berlin. 